\title{
THYROTOXICOSIS HYPOKALAEMIC PERIODIC PARALYSIS WITH ACQUIRED BARTTER-LIKE PHENOTYPE
}

\author{
Samarendra Nath Das ${ }^{1}$, Madhusmita Patnaik ${ }^{2}$, Ravi Ranjan Kindo ${ }^{3}$, Bibhuti Bhusan Mohanta ${ }^{4}$
}

\author{
1 Professor, Department of Medicine, SCB Medical College, Cuttack, Odisha, India. \\ ${ }^{2}$ Assistant Professor, Department of Medicine, SCB Medical College, Cuttack, Odisha, India. \\ 3Junior Resident, Department of Medicine, SCB Medical College, Cuttack, Odisha, India. \\ ${ }^{4} J u n i o r$ Resident, Department of Medicine, SCB Medical College, Cuttack, Odisha, India.
}

HOW TO CITE THIS ARTICLE: Das SN, Patnaik M, Kindo RR, et al. Thyrotoxicosis hypokalaemic periodic paralysis with acquired Bartter-like phenotype. J. Evolution Med. Dent. Sci. 2017;6(95):7060-7062, DOI: 10.14260/jemds/2017/1532

\section{PRESENTATION OF CASE}

A Hindu male patient aged about forty years admitted to the medicine ward due to weakness in both proximal and distal muscles of both the limbs since last 10 days. Subsequently, he was unable to move both legs after 1 week. He was experiencing pain abdomen 1 day before admission. There was no history of fever, loose motion, convulsion, sensory loss and bowel or bladder involvement. He had a past history of weakness and muscle cramps for last one year for which he was treated several times. During that period, he noticed weight loss despite good appetite. There was increase in frequency of urination around 9 to 10 times a day, particularly more during the night time for which he wakes up several times. He had no past history of any gastrointestinal or cardiovascular problems, although he felt uneasiness with sweating sometimes. He had undergone such type of repeated attack mostly in the night during this period, which was followed after a heavy meal or after exertion. The patient was a non-smoker and a farmer by profession, married since 5 years with no children. He was not under any medications or addicted to any drug. There was no evidence of any similar illness within the family.

\section{DIFFERENTIAL DIAGNOSIS}

The differential diagnosis in this condition, which includes the diseases like Hypokalaemic palsy, Guillain-Barré syndrome, channelopathies like hypokalaemic periodic paralysis and tubulopathies like Bartter and Gitelman syndrome.

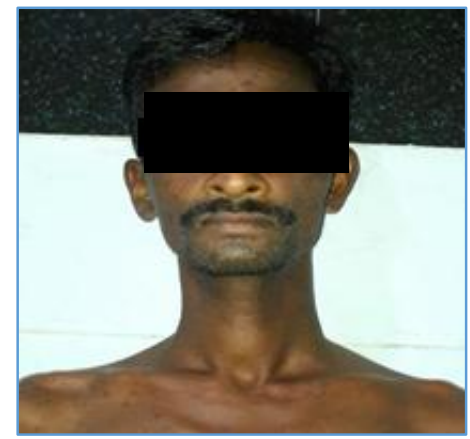

Figure 1. The Picture of the Patient showing Thyrotoxicosis Features

'Financial or Other Competing Interest': None.

Submission 01-11-2017, Peer Review 05-12-2017,

Acceptance 11-12-2017, Published 23-12-2017.

Corresponding Author:

Dr. Madhusmita Patnaik,

Assistant Professor,

Department of Medicine,

S.C.B. Medical College

Cuttack - 753007, Odisha, India.

E-mail:dr.madhusmita.med@gmail.com

DOI: $10.14260 /$ jemds $/ 2017 / 1532$

\section{(c) $(1) \$$}

\section{CLINICAL DIAGNOSIS}

The patient was conscious and well oriented with pulse rate of 96/ min, blood pressure of 86/ $60 \mathrm{mmHg}$ over right arm in supine position, respiratory rate of $18 / \mathrm{min}$ and temperature of 98.6 degrees Fahrenheit. He was 5 feet tall with thin and lean built, having the weight of $38 \mathrm{~kg}$. Severe dehydration with mild anaemia were seen during examination. The exophthalmos feature with all the eye signs of thyrotoxicosis were observed. A thyroid swelling of each lobe of $5 \mathrm{~cm}$ width and $4 \mathrm{~cm}$ length was presented with firm in consistency, diffuse, non-tender, grade 2 goitre, moving with deglutination without any bruit and thrill (Fig-1). Neurological examination revealed normal higher function test without any cranial nerve involvement. Examination of the motor system showed hypotonia of both upper and lower limb with a power of 2/5 on all the limbs. All the deep tendon jerks were absent, although plantar reflex was bilaterally flexor. The sensory or autonomic system revealed no abnormality. There was no neck stiffness, although weakness in the neck muscles were present. Electrolyte test was done on emergency basis, which revealed the features of hypokalaemia and hyponatraemia, which was subsequently confirmed by ECG showing the ' $U$ ' wave. Hence, a provisional diagnosis of thyrotoxicosis hypokalaemic palsy was made.

\section{PATHOLOGICAL DISCUSSION}

In 1902, Rosenfeld was the first to document the association between thyrotoxicosis with hypokalaemia. ${ }^{1}$ Muscular weakness associated with thyrotoxicosis can be due to thyrotoxic myopathy, periodic paralysis or any myasthenic symptoms. Amongst these, the periodic paralysis in thyrotoxicosis is characterised by the neuromuscular symptoms of recurrent episode of acute onset severe hypokalaemia and profound proximal muscle weakness, which is similar to hypokalaemic periodic paralysis, except for the presence of signs and symptoms of thyrotoxicosis. Thyrotoxicosis is associated with hypokalaemic periodic palsy, hypercalciuria, hypercalcaemia and hypocalcaemia also. ${ }^{2,3,4}$ The serum concentrations of electrolytes like $\mathrm{Na}, \mathrm{K}$ and $\mathrm{Cl}$ are usually normal in hyperthyroidism. ${ }^{2,5}$ On kidney, the metabolism of sodium and potassium with the help of the thyroid hormones act upon the tubular transport of sodium through sodium-potassium ATP pump ( $\mathrm{Na} / \mathrm{K}$ ATPase), which in turn increases the potassium permeability in the proximal tubular membrane resulting in hyponatraemia and hypokalaemia with urinary loss of $\mathrm{Na}$ and K.6,7 The increase of thyroid hormone activity at kidney level is coexisted by an increase in the absorption of calcium in the tubules without affecting magnesium resulted into hypercalcaemia and hypocalciuria.6,7 Thyroid hormone also stimulates the release of renin by the juxtaglomerular cells by a mechanism 
independent of the ouabain-sensitive sodium pump and protein synthesis, which consequently influences kidney angiotensinase activity. Renin-Angiotensin System (RAS) hyperactivity is associated with hyperthyroidism. ${ }^{6}$ As a consequence, Plasma Renin Activity (PRA), plasma angiotensinogen, Angiotensin II and aldosterone levels are directly related to plasma thyroid hormone concentrations. There is an increase in Renal Plasma Flow (RPF) and Glomerular Filtration Rate (GFR) in thyrotoxicosis leading to symptom of polyuria. Haemodynamic changes like increase in systolic volume, heart rate and the cardiac output combined with a decrease in peripheral vascular resistance, also responsible in the modification in renal function with hyperthyroidism. This is due to the increased continuing demands of thyroid hormone leads to hypermetabolic activity and the increased need to dissipate excess heat due to hyperthyroid activity.6,8,7 Although, the majority of cases of thyrotoxicosis associated with Graves' disease, it can appear with hyperthyroidism of any origin. Thyrotoxic hypokalaemic paralysis patients have been associated with the features of thyroiditis, toxic adenoma or toxic nodular goitre. The important precipitating factors of hypokalaemic paralysis due to thyrotoxicosis reported in the literature include more carbohydrate intake, vigorous exercise, acute upper respiratory tract infection, trauma, high-salt diet, emotional stress, cold exposure, alcohol intake, menstruation and drugs usage. Thyrotoxic Periodic Palsy (TPP), which may be preceded by prodromal symptoms like muscle pain, cramps or muscles stiffness of the affected limbs. So the hyperthyroidism results in hypokalaemia, hypophosphataemia, mild hypomagnesaemia, hypercalcaemia, normal bicarbonate level and normal blood $\mathrm{pH}$. Urinary findings in this condition are low potassium excretion rate, hypercalciuria and hypophosphaturia. ${ }^{9}$ In our patient low electrolyte conditions like hyponatraemia, hypokalaemia, hypomagnesaemia, hypocalcaemia with urinary loss of electrolytes like $\mathrm{Na}, \mathrm{Ca}, \mathrm{Cl}$ and $\mathrm{Mg}$ along with increased renin and aldosterone level, which was inconsistent with thyrotoxicosis, hence leads to find other associated conditions.

Later on in the year 1962, Bartter and his co-workers described two male patients of black American in origin, both aged 5 and 25 years were having the features of hypokalaemia, mild hypomagnesaemia, hypochloraemic metabolic alkalosis, decreased urinary concentrating and diluting ability, hypercalciuria with nephrocalcinosis, increased urinary prostaglandin excretion and hypotension.2,5 Along with that, there was also hyperplasia and hypertrophy of the Juxtaglomerular apparatus.2,5 Bartter syndrome is very rare, which is mostly seen in antenatal cases or in neonates. So far very few cases have been reported in adults which showed its association with chronic sialadenitis, pulmonary tuberculosis and exposure to aminoglycosides like gentamycin. ${ }^{10,11,12,13}$

Bartter syndrome is a rare autosomal recessive disorder resulting from the mutations affecting the ion transport proteins in thick ascending loop of Henle. This is due to loss of the lumen-positive electrical transport potential which drives the paracellular reabsorption of sodium, calcium and magnesium causing sodium and chloride wasting, hypercalciuria and mild hypomagnesaemia in thick ascending loop of Henle. 8 Hypovolaemia from impaired sodium and chloride reabsorption either in the thick loop of Henle or the Distal Convulated Tubule activates the renin-angiotensin- aldosterone system (RAAS). The clinical syndrome may even mimic the effects of chronic ingestion of a loop diuretic. Hence, giving a clinical picture of salt wasting like hypokalaemic metabolic alkalosis, hyponatraemia, hypokalaemia, hypochloraemic metabolic alkalosis, hypercalciuria, mild hypomagnesaemia, increased urinary prostaglandin excretion, increased plasma renin and aldosterone levels. After evaluating the molecular causes and mechanisms of individual Tubulopathies, the Bartter syndrome is further classified into Bartter-like syndromes according to the underlying genetic defect. ${ }^{8}$ In our case, initially thyrotoxicosis hypokalaemic palsy was suspected. Hypokalaemia was also considered as he presented with flaccid paralysis of all four limbs, and without any past history of gastroenteritis, diuretic intake, viral infection and pulmonary tuberculosis. Initial investigations shown $($ Table 1,4$)$ suggested hyponatraemia, hypokalaemia, hypocalcaemia, hypomagnesaemia and hypochloraemia with hypercalciuria, high renin and aldosterone levels. Arterial Blood Gas (ABG) analysis had revealed compensatory metabolic alkalosis. All the above findings are consistent with Bartter-like phenotype. Due to the presence of thyrotoxicosis hypokalaemic paralysis with metabolic alkalosis, a diagnosis was made, which finally concluded as a case of thyrotoxicosis hypokalaemic paralysis with acquired Bartter-like phenotype.

\section{DISCUSSION OF MANAGEMENT}

He was initially treated with Inj. KCL, $3 \% \mathrm{NaCl}$ and normal saline. Despite the treatment, he did not improve rather he developed carpopedal spasm the next day. Clinical finding was shown as positive Trousseau's sign without Chvostek sign. On general examination, the systolic blood pressure was between 80 to $90 \mathrm{mmHg}$ and diastolic blood pressure between 50 to 60 $\mathrm{mmHg}$ throughout the evaluation period. Laboratory investigations suggested severe hyponatraemia, hypokalaemia, hypocalcaemia and hypomagnesaemia (Table 1). Thyroid profile revealed raised free $\mathrm{T} 3$ and free $\mathrm{T} 4$ with decreased $\mathrm{TSH}$, which is suggestive of primary hyperthyroidism. Serum PTH was normal with increased renin and aldosterone level (Table 2). He had excess loss of urinary sodium, calcium and chloride with total urinary output recorded up to 9 litres/ day (Table 3). ABG showed a compensated metabolic alkalosis (Table 4). USG of the thyroid indicated thyroiditis with b/l cervical lymphadenopathy. FNAC of thyroid had suggestive of colloid goitre. USG of the abdomen and pelvis as well as CECT scan of abdomen had the normal findings. Finally, taking all into account, he was diagnosed as thyrotoxicosis hypokalaemic paralysis with acquired Bartter-like phenotype.

He was treated with Carbimazole tablet (10 mg) thrice a day and propranolol tablet (20 mg) twice a day along with sodium, potassium, calcium and magnesium supplements. He improved on $5^{\text {th }}$ day with a power of $5 / 5$, though normal electrolyte level was never recorded. He was discharged with same medications with advice for followup in OPD.

He followed up after 4 weeks and despite giving sodium, potassium, calcium and magnesium supplements his serum electrolyte was never recorded normal. The treatment should be supplements of potassium, magnesium and sodium for lifelong. Diuretics like spironolactone or amiloride can be helpful in high doses. NSAIDS like Indomethacin is mostly used 
to reduce the sodium loss and polyuria. Angiotensin-I converting enzyme inhibitors and potassium supplements are used in combination to reduce the potassium loss. ${ }^{13,14}$

\section{FINAL DIAGNOSIS}

This is a rare case with features of thyrotoxicosis, hyponatraemia, hypokalaemia, hypomagnesaemia and hypocalcaemia with urinary loss of sodium, calcium, chloride and magnesium with compensated metabolic alkalosis with increased renin and aldosterone level with hypotension and sudden onset of acute quadriparesis. Hence, taking all those above into account, it was concluded as a case of thyrotoxicosis hypokalaemic paralysis with acquired Bartter-like phenotype.

\begin{tabular}{|c|c|c|c|c|c|c|}
\hline & $\begin{array}{c}\mathbf{1}^{\text {st }} \\
\text { Day }\end{array}$ & $\begin{array}{c}\mathbf{3}^{\text {rd }} \\
\text { Day }\end{array}$ & $\begin{array}{c}\mathbf{5}^{\text {th }} \\
\text { Day }\end{array}$ & $\begin{array}{c}\mathbf{7}^{\text {th }} \\
\text { Day }\end{array}$ & $\begin{array}{c}\mathbf{9 t h}^{\text {th }} \\
\text { Day }\end{array}$ & $\begin{array}{c}\text { On } \\
\text { Follow- } \\
\text { Up }\end{array}$ \\
\hline $\begin{array}{c}\text { Serum Na+ } \\
(135-145 \mathrm{mEq} / \mathrm{L})\end{array}$ & 124 & 127 & 126 & 126 & 132 & 118 \\
\hline $\begin{array}{c}\text { Serum K+ } \\
(3.5-5.0 \mathrm{mEq} / \mathrm{L})\end{array}$ & 1.8 & 2.8 & 2.4 & 2.6 & 2.9 & 2.4 \\
\hline $\begin{array}{c}\text { Serum Ca++ } \\
(\mathrm{ionised}) \\
(1.1-1.4 \mathrm{mmol} / \mathrm{L})\end{array}$ & 0.90 & 0.96 & 0.98 & 0.96 & 1.02 & 1.0 \\
\hline $\begin{array}{c}\text { Serum Mg++ } \\
(1.6-2.3 \mathrm{mg} / \mathrm{dL})\end{array}$ & 1.0 & 1.3 & 1.2 & 1.2 & 1.3 & 0.9 \\
\hline $\begin{array}{c}\text { Serum Phosphate } \\
(2.5-5.0 \mathrm{mg} / \mathrm{dL})\end{array}$ & 3.1 & 3.4 & 3.6 & 3.1 & 3.8 & 3.2 \\
\hline $\begin{array}{c}\text { Serum Cl- } \\
(85-115 \mathrm{mmol} / \mathrm{L})\end{array}$ & 126 & 120 & 122 & 118 & 114 & 120 \\
\hline \multicolumn{7}{|c|}{ Table 1. Serum Electrolyte Reports during } \\
\hline
\end{tabular}

\begin{tabular}{|c|c|}
\hline Free T3 (2.02-4.43 pg/mL) & 21.19 \\
\hline Free T4 $(0.93-1.71 \mathrm{ng} / \mathrm{mL})$ & 6.00 \\
\hline TSH $(0.27-5.0 \mathrm{u} / \mathrm{mL})$ & 0.005 \\
\hline PTH $(15-65 \mathrm{pg} / \mathrm{mL})$ & 24.38 \\
\hline $\begin{array}{c}\text { Serum Aldosterone } \\
(1.76-23.2 \mathrm{ng} / \mathrm{mL})\end{array}$ & 40.2 \\
\hline $\begin{array}{c}\text { Plasma Renin } \\
(2.80-39.90 \text { microIU) }\end{array}$ & 100.60 \\
\hline \multicolumn{2}{|c|}{ Table 2. Hormone Analysis } \\
\hline
\end{tabular}

\begin{tabular}{|c|c|}
\hline Urinary Sodium & $495 \mathrm{mEq} /$ day $(40-220)$ \\
\hline Urinary Potassium & $63.9 \mathrm{mEq} /$ day $(25-125)$ \\
\hline Urinary Calcium & $900 \mathrm{mg} /$ day $(100-400)$ \\
\hline Urinary Magnesium & $360 \mathrm{mg} /$ day \\
\hline Urinary Chloride & $468 \mathrm{mEq} /$ day $(110-250)$ \\
\hline Total Volume & $9000 \mathrm{~mL} /$ day \\
\hline \multicolumn{2}{|c|}{ Table 3. 24-Hour Urine Analysis } \\
\hline
\end{tabular}

\begin{tabular}{|c|c|}
\hline Haemoglobin & $9.6 \mathrm{gm} \%$ \\
\hline Total Leucocyte Count & $7200 / \mathrm{cmm}$ \\
\hline Differential Count & $\mathrm{N} 68 \%, \mathrm{~L} 29 \%, \mathrm{E} 2 \%, \mathrm{~B} 1 \%, \mathrm{M} 0 \%$ \\
\hline Total Platelet Count & $2.6 \mathrm{lacs} / \mathrm{cmm}$ \\
\hline $\begin{array}{c}\text { Erythrocyte } \\
\text { Sedimentation Rate }\end{array}$ & $10 \mathrm{~mm}$ fall in $1^{\text {st } \mathrm{hr}}$ \\
\hline Haematocrit & $30 \%$ \\
\hline S. urea & $28 \mathrm{mg} / \mathrm{dL}$ \\
\hline
\end{tabular}

\begin{tabular}{|c|c|}
\hline S. creatinine & $1.0 \mathrm{mg} / \mathrm{dL}$ \\
\hline Liver Function Test & $\begin{array}{c}\text { Bil (T)1 mg/dL, Bil (D) } 0.5 \mathrm{mg} / \\
\text { dL, SGOT-115 IU/L, SGPT-52 IU/L, } \\
\text { ALP-197 IU/L }\end{array}$ \\
\hline S. protein & $5.6 \mathrm{gm} / \mathrm{dL}$ \\
\hline S. albumin & $2.9 \mathrm{gm} / \mathrm{dL}$ \\
\hline Random Blood Sugar & $140 \mathrm{mg} / \mathrm{dL}$ \\
\hline Blood ph & 7.43 \\
\hline $\begin{array}{l}\text { Urine Routine and } \\
\text { Microscopic }\end{array}$ & $\begin{array}{l}\text { Alb- nil, Sugar- nil, Pus Cell- 1-2, } \\
\text { Epi Cell- 4-6, RBC- } 0\end{array}$ \\
\hline \multicolumn{2}{|c|}{ Table 4. Other Investigations } \\
\hline
\end{tabular}

\section{REFERENCES}

[1] Rosenfeld M. Akute aufsteigende lahmungen bei morbus basedow. Berl Klin Wochenschr 1902;39:53840 .

[2] Longo DL, Fauci AS, Kasper DL, et al. Harrison's Principles of Internal Medicine. Vol 2. 19 th edn. The McGraw Hill Companies 2015;2293-8.

[3] Raja SB, Anjanappa JC. A rare case of hypocalcemia in hyperthyroidism. Int J Health Allied Sci 2012;1(2):1124.

[4] Bieigel Y, Arie R, Wysenbeek AJ, et al. Hypocalcaemia, a possible manifestation of thyrotoxicosis. Postgraduate Medical Journal 1983;59(691):317-9.

[5] Bartter F, Pronove P, Gill JR, et al. Hyperplasia of the juxtaglomerular complex with hyperaldosteronism and hypokalemic alkalosis. A new syndrome. Am J Med 1962;33:811-28.

[6] Mariani LH, Berns JS. The Renal manifestations of thyroid disease. J Am Soc Nephrol 2012;23(1):22-6.

[7] Iglesias P, Dı'ez JJ. Thyroid dysfunction and kidney disease. European Journal of Endocrinology 2009;160(4):503-15.

[8] Vargas F, Rodri'guez-Go'mez I, Vargas-Tendero P, et al. The renin-angiotensin system in thyroid disorders and its role in cardiovascular and renal manifestations. Journal of Endocrinology 2012;213(1):25-36.

[9] Kung AWC. Thyrotoxic periodic paralysis: a diagnostic challenge. The Journal of Clinical Endocrinology \& Metabolism 2006;91(7):2490-5.

[10] Casatta L, Ferraccioli GF, Bartoli E. Hypokalemic alkalosis, acquired Gitelman's and Bartter syndrome in chronic sialoadenitis. $\mathrm{Br} \quad \mathrm{J}$ Rheumatol 1997;36(10):1125-8.

[11] Stoian M, Chirac D, Bontas E, et al. Bartter syndrome with pulmonary Tuberculosis: a shortly outlook. Medica- J Clin Med 2007;2(4):332-9.

[12] Workeneh B, Sangsiraprabha W, Addison D, et al. A novel case of persistent barters-like syndrome associated with gentamycin exposure. Saudi J Kidney Dis Transpl 2013;24(1):144-6.

[13] Gadwalkar SR, Murty PR, Raghavendra K, et al. Acquired barter like phenotype JAPI 2015;63:78-9.

[14] Brenner BM. Brenner and Rectors the Kidney. Vol 2. 9th edn. Philadelphia: Elsevier 2012;1606:2645-6. 